\title{
Effects of cleaning agents on bond strength to dentin
}

\section{Efeitos de agentes de limpeza na resistência adesiva à dentina}

\author{
Celso Rosin* \\ Victor Elias Arana-Chavez $z^{* *}$ \\ Narciso Garone Netto*** \\ Maria Aparecida Alves de Cerqueira Luz ${ }^{* * *}$
}

\begin{abstract}
The cleaning of cavity walls aims to improve adhesive restorative procedures and longevity of restorations. This study has compared the effect of three cleaning agents - sodium bicarbonate jet (Profi II, Dabi Atlante, São Paulo, Brazil); pumice paste plus a biologic detergent (Tergestesim, Probem, São Paulo, Brazil); air water spray - on the bond strength between dentin and two different adhesive systems: Clearfil SE Bond (Kuraray, Kioto, Japan) and Scotchbond Multi-Purpose Plus (3M-ESPE, São Paulo, Brazil). Six groups (n:10) of dental fragments obtained from young adult extracted teeth were prepared, and each one received one of the listed surface cleaning techniques. After the adhesive application, a cone-shaped test body was built with AP-X (Kuraray, Kioto, Japan) or Z100 (3M-ESPE, São Paulo, Brazil) composite resins, using a Teflon matrix. The specimens were tested for tensile bond strength after one-week storage in distilled water at $37^{\circ} \mathrm{C}$. Two pairs of fractured specimens of each group were randomly chosen and processed for scanning electron microscopy (SEM) analysis. ANOVA test of the bond strength values showed no statistical differences among the cleaning agents and neither between their interactions with the bonding systems. Upon SEM analysis, most surfaces showed mixed fractures of adhesive and cohesive failures in bonding resin to dentin. Based on statistical and SEM analysis, it was concluded that the cleaning agents studied did not interfere with the bond strength of the adhesive systems used to dentin.
\end{abstract}

DESCRIPTORS: Dental prophylaxis; Composite resins; Dentin-bonding agents; Dentin.

\begin{abstract}
RESUMO: A limpeza das paredes cavitárias é um passo importante na clínica odontológica e visa otimizar os procedimentos adesivos e a longevidade das restaurações. O presente estudo comparou o efeito de três agentes de limpeza cavitária - jato abrasivo de bicarbonato de sódio/ar/água (Profi II, Dabi Atlante, São Paulo, Brasil); pasta de pedra-pomes e água, somada a um detergente biológico (Tergestesim, Probem, São Paulo, Brasil); e spray de ar/água - na resistência adesiva entre dentina e dois tipos de adesivos dentais: Clearfil SE Bond ("self-etching") (Kuraray, Kioto, Japão) e Scotchbond Multi-Purpose Plus (“all-etching”) (3M-ESPE, São Paulo, Brasil). Seis grupos de espécimes $(n=10)$ obtidos a partir de elementos dentais humanos extraídos por indicação foram preparados e cada um recebeu um dos tratamentos de superficie. Após aplicação dos adesivos, uma porção tronco-cônica de resina composta (AP-X, Kuraray, Kioto, Japão/Z-100; 3M-ESPE, São Paulo, Brasil) foi construída sobre os espécimes, com o auxílio de uma matriz bipartida de teflon e uma mesa metálica adaptadora para adaptação na máquina de ensaio de tração. Após armazenamento em água destilada a $37^{\circ} \mathrm{C}$ por 7 dias, os mesmos foram submetidos às provas de tração. Dois pares de cada grupo foram escolhidos aleatoriamente e processados para observação ao microscópio eletrônico de varredura (MEV). A análise estatística dos valores obtidos demonstrou que não houve diferenças significantes entre as técnicas de limpeza empregadas e nem entre a interação destas com os adesivos dentais, e as observações ao MEV revelaram uma predominância de fraturas mistas ocorridas na interface dentina/resina. Baseados nas análises estatísticas e nas observações ao $\mathrm{MEV}$, concluiu-se que as técnicas de limpeza empregadas não interferem na resistência adesiva entre a dentina e os sistemas adesivos estudados, nas condições experimentais adotadas.
\end{abstract}

DESCRITORES: Profilaxia dentária; Resinas compostas; Adesivos dentinários; Dentina.

\section{INTRODUCTION}

Different kinds of surface treatments employed for restorative and preventive procedures on dental structures have been assessed in important investigations $s^{1,3,6,7}$. The objective of surface treatments is to obtain the maximum adhesive interaction to dental structures.

The recent evolution of adhesive systems has brought on the refinement of all-etch adhesive

\footnotetext{
* Junior Doctor, Department of Restorative Dentistry, School of Dentistry; **Chair Professor, Department of Oral Histology, Institute of Biomedical Sciences; ${ }^{* * *}$ Chairman, Department of Restorative Dentistry, School of Dentistry; ${ }^{* * * *}$ PhD, Professor, Department of Restorative Dentistry, School of Dentistry - University of São Paulo.
} 
Rosin C, Arana-Chavez VE, Garone Netto N, Luz MAAC. Effects of cleaning agents on bond strength to dentin. Braz Oral Res 2005;19(2):127-33.

systems (using $32 \%$ or $37 \%$ phosphoric acid) ${ }^{2,6}$, and the development of self-etching adhesive systems (organic acids and/or acidic monomers in the primer), reducing clinical steps ${ }^{15}$. Differences among adhesive systems require important considerations regarding the adhesion to dentin, such as: treatment used in the dental surface, humidity of dentin ${ }^{2}$, smear layer removal ${ }^{10}$, collagen network collapse ${ }^{15}$, and depth of resin tag formation inside dentinal tubules ${ }^{5,9}$.

A previous cleaning of dental surfaces must be done, even when performing the all-etch technique, to remove dental plaque, stain, and/or any other amorphous substance adhered to the tooth, which may interfere in the demineralization process ${ }^{1}$.

The use of pumice paste plus a biologic detergent, applied with a rubber cup, has predominated in dental prophylaxis and in cavity cleaning, because they promote satisfactory surface cleaning, improving superficial energy to receive the demineralization solution ${ }^{7}$. However, some authors ${ }^{8,14}$ noted that when this method is used on a flat enamel surface, it produces a surface covered by pumice residues condensed by the rubber cup, which negatively interferes with adhesion, making sodium bicarbonate jet a preferred cleaning agent.

There is some controversy about the efficacy of sodium bicarbonate jet as a cleaning method, and about its effects on dental tissues ${ }^{7,13}$ before adhesive procedures $^{1,8,14}$. Bester et al. ${ }^{3}$ (1995) showed that it can cause dentin erosion, residue accumulation on the tooth surface and degradation of the cavity margins. Hoeppner et al. ${ }^{8}$ (1998) showed that it is more effective than the pumice paste technique on enamel of occlusal surfaces for deeply cleaning pits and fissures. Armas-Vega ${ }^{1}$ (2001) detected an irregular pattern of demineralization when sodium bicarbonate jet was used on enamel surface before etching with $37 \%$ phosphoric acid.

The related literature reports a great number of other cavity cleaning agents for dentinal surface, such as: phosphoric acid ${ }^{4,9}$, sodium hypochlorite $^{6,10}$, EDTA ${ }^{4,5,6}$, hydrogen peroxide ${ }^{6}$, polyacrylic acid $^{6}$, prophylactic pastes ${ }^{5,14}$, and aluminum oxide jet $^{5}$.

Their effect ranges from the simple removal of some contaminants to the total or partial removal of the smear layer, promoting demineralization that can facilitate the interaction between resin and dentin, although changing dentinal permeability and all the phenomena related to $\mathrm{it}^{10}$.

The aim of this research is to compare the effect of sodium bicarbonate jet, pumice/water paste plus a biologic detergent, and air/water spray (control) as cavity cleaning agents on the tensile bond strength of two kinds of dental adhesives to dentin.

\section{MATERIALS AND METHODS}

Thirty human third molars extracted for different reasons, with the consent of patients and with the approval of the Research Ethics Committee, were used. Their roots were removed and their crowns were half-sectioned following a buccolingual orientation. The coronal fragments were embedded in self-curing acrylic resin (Clássico Ltda., São Paulo, Brazil) to leave their enamel surfaces exposed just for their manipulation and preparation in the polishing device (Ecomet 3, Buehler Co., IL, USA), under running water, to obtain a flat dentin surface, confirmed through observation with a magnifying glass (Olympus, Tokyo, Japan). On the center of the dentinal surface of each specimen, a $3 \mathrm{~mm}$ diameter circle area was defined, using a mold, being the whole surrounding surface covered by two layers of an acid-resistant varnish (Revlon nail varnish, São Paulo, Brazil).

The specimens were randomly divided into six groups $(n=10)$ that received surface treatments, as described in Table 1, followed by the application of Scotchbond Multi-Purpose Plus (SBMP) and Clearfil SE Bond (CSEB) adhesive systems. Exactly on the area defined by the varnish, a Teflon matrix and an adapting metallic table were positioned to allow the placement of the adhesive systems (SBMP/CSEB) and composite resin layers (Z-100/Clearfil AP-X) until obtaining a coneshaped test specimen. This shape is necessary for the traction test. The sodium bicarbonate jet (Profi II, Dabi Atlante, São Paulo, Brazil), under 60 pound pressure, was applied $5 \mathrm{~mm}$ distant from the dentinal surface with a $90^{\circ}$ incidence, while the biologic detergent (Tergestesim, Probem, São Paulo, Brazil) was applied rubbing a cotton pellet on the specimen's surface.

After storage in distilled water (Cinord Sul, Ribeirão Preto, Brazil) $\left(37^{\circ} \mathrm{C}\right.$ for 07 days $)$, the specimens were submitted to the traction tests using an Instron Universal Testing Machine (Instron Corporation, Canton, USA), with $0.5 \mathrm{~mm} / \mathrm{s}$ speed. The pairs then identified were again stored in distilled water. Two pairs of each group were randomly chosen, totalizing 12 pairs of fractured composite/dentin specimens. A treatment with $2 \%$ hydrochloric acid (Indústria Farmacêutica Rioquímica Ltda., São José do Rio Preto, Brazil) for 2 minutes 
Rosin C, Arana-Chavez VE, Garone Netto N, Luz MAAC. Effects of cleaning agents on bond strength to dentin. Braz Oral Res 2005;19(2):127-33.

TABLE 1 - Surface Treatments and Adhesive Systems.

\begin{tabular}{|c|c|c|c|c|}
\hline & Treatments & Acid Etching & Adhesive Systems & Composite Resin \\
\hline Group 01 - SS & - Air/Water Spray - 15 s & $\begin{array}{c}\text { Phosphoric acid } \\
37 \%-10 \mathrm{~s}\end{array}$ & $\begin{array}{l}\text { Scotchbond } \\
\text { Multipurpose* }\end{array}$ & $Z-100 *$ \\
\hline Group 02 - JBS & $\begin{array}{l}\text { - Sodium Bicarbonate Jet - } 15 \mathrm{~s} \\
\text { - Air/Water Spray - } 15 \mathrm{~s}\end{array}$ & $\begin{array}{c}\text { Phosphoric acid } \\
37 \%-10 \mathrm{~s}\end{array}$ & $\begin{array}{l}\text { Scotchbond } \\
\text { Multipurpose* }\end{array}$ & $Z-100 *$ \\
\hline Group 03 - PTS & $\begin{array}{l}\text { - Pumice paste - } 15 \mathrm{~s} \\
\text { - Air/Water Spray - } 15 \mathrm{~s} \\
\text { - Biologic detergent - } 15 \mathrm{~s} \\
\text { - Air/Water Spray - } 15 \mathrm{~s}\end{array}$ & $\begin{array}{l}\text { Phosphoric acid } \\
37 \%-10 \mathrm{~s}\end{array}$ & $\begin{array}{l}\text { Scotchbond } \\
\text { Multipurpose* }\end{array}$ & $Z-100 *$ \\
\hline Group 04 - SC & - Air/Water Spray - 15 s & - & Clearfil SE Bond** & Clearfil AP-X** \\
\hline Group 05 - JBC & $\begin{array}{l}\text { - Sodium Bicarbonate Jet - } 15 \mathrm{~s} \\
\text { - Air/Water Spray - } 15 \mathrm{~s}\end{array}$ & - & Clearfil SE Bond** & Clearfil AP-X** \\
\hline Group 06 - PTC & $\begin{array}{l}\text { - Pumice paste - } 15 \mathrm{~s} \\
\text { - Air/Water Spray - } 15 \mathrm{~s} \\
\text { - Biologic detergent - } 15 \mathrm{~s} \\
\text { - Air/Water Spray - } 15 \mathrm{~s}\end{array}$ & - & Clearfil SE Bond** & Clearfil AP-X** \\
\hline
\end{tabular}

*(3M-ESPE - São Paulo - Brazil); **(Kuraray - Kyoto - Japan).

TABLE 2 - Shear bond strength values (MPa).

\begin{tabular}{|c|c|c|c|c|c|c|c|c|c|c|c|c|}
\hline $\begin{array}{l}\text { Specimens } \\
\text { Groups }\end{array}$ & 1 & 2 & 3 & 4 & 5 & 6 & 7 & 8 & 9 & 10 & M & S.D. \\
\hline Group 01 - SS & 9.54 & 5.71 & 8.86 & 23.18 & 7.83 & 17.57 & 2.64 & 7.96 & 13.68 & 5.01 & 10.20 & 6.254 \\
\hline Group $02-$ JBS & 3.84 & 6.40 & 8.80 & 4.04 & 6.79 & 3.62 & 4.47 & 5.80 & 4.81 & 13.97 & 6.25 & 3.153 \\
\hline Group 03 - PTS & 6.86 & 8.61 & 2.09 & 9.13 & 4.76 & 3.19 & 17.90 & 11.91 & 14.61 & 4.27 & 8.33 & 5.178 \\
\hline Group 04 - SC & 13.88 & 8.18 & 9.11 & 24.93 & 19.65 & 31.97 & 18.45 & 14.48 & 24.77 & 28.52 & 19.39 & 8.083 \\
\hline Group 05 - JBC & 17.56 & 16.35 & 11.82 & 18.16 & 14.31 & 12.88 & 6.02 & 14.45 & 18.29 & 27.40 & 15.72 & 5.515 \\
\hline Group 06 - PTC & 14.26 & 20.88 & 14.20 & 2.37 & 32.90 & 6.04 & 9.12 & 3.53 & 17.56 & 12.30 & 13.32 & 9.114 \\
\hline
\end{tabular}

M: mean. SD: standard deviation.

followed by dehydration through the immersion in increasing concentrations of ethanol (Indústria Farmacêutica Rioquímica Ltda., São José do Rio Preto, Brazil) was applied on these surfaces in order to remove organic components from the specimens' surfaces. After fixation in aluminum stubs, they were sputter-coated with gold (Balzers SCD-050, Liechtenstein, Germany) for SEM observation (Jeol 6100, Jeol, Tokyo, Japan).

\section{RESULTS}

Mean values of the bond strength tests and respective standard deviations are shown in Table 2. Descriptive analysis showed that CSEB presented higher numeric values of bond strength than SBMP. The SBMP groups presented the lowest values of bond strength: the JBS group presented the lowest means of bond strength values, followed by the PTS group, and by the SS group (control), which presented the highest mean values. The CSEB groups behaved differently: the PTC group presented the lowest mean values of bond strength, followed by the JBC group, and by the $\mathrm{SC}$ group (control), which presented the highest mean values.

SEM analysis of the dentin and resin surfaces obtained from the bond strength tests revealed the occurrence of mixed fractures (adhesive and cohesive) in almost all the specimens. When these specimens were observed under higher magnifications, distinct areas of adhesive fractures and cohesive fractures inside the same specimen could be distinguished.

Figure 1A (PTC group) shows part of the fracture that occurred between the adhesive layer and dentin, where resin tags obliterating the dentinal tubules can be observed (adhesive fracture). In 
Rosin C, Arana-Chavez VE, Garone Netto N, Luz MAAC. Effects of cleaning agents on bond strength to dentin. Braz Oral Res 2005;19(2):127-33.
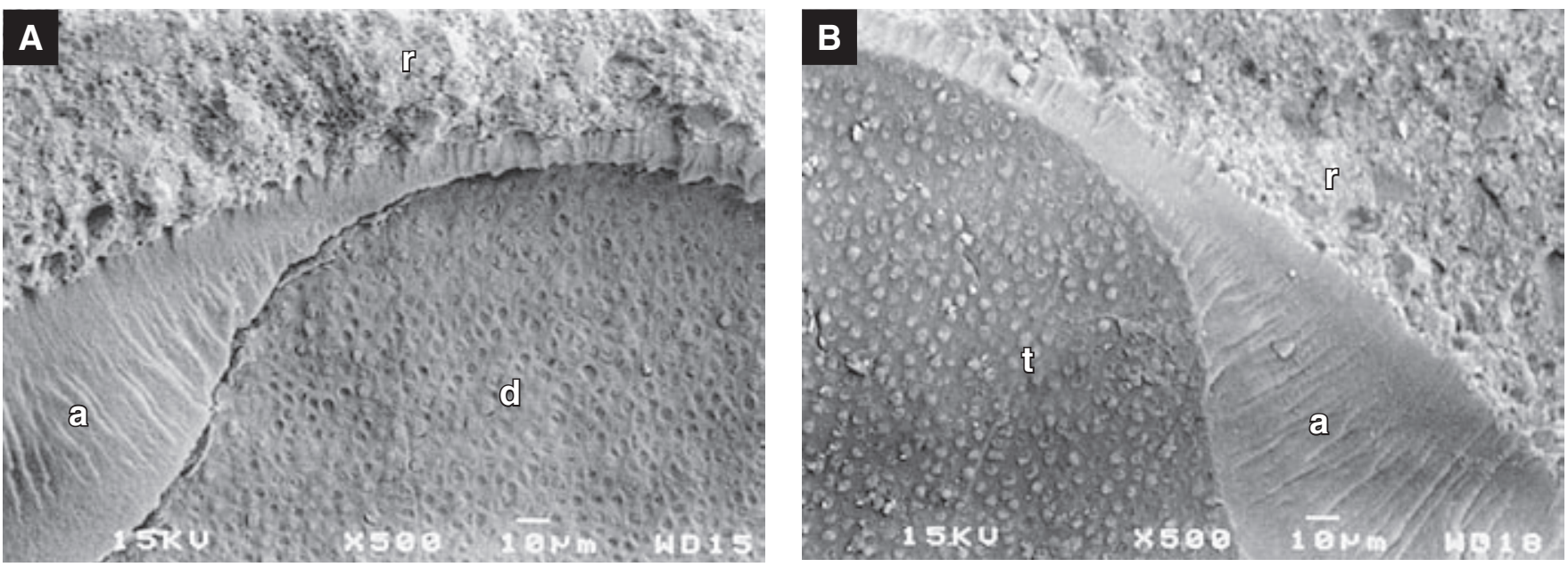

FIGURES 1A AND 1B - Scanning electron micrographs of the dental fragment in 1 A (500 X) and composite resin fragment in 1B (PTC group)(500 X). The adhesive layer (a), the composite resin layer (r), obliterated dentinal tubule apertures $(\mathbf{d})$, and fractured resin tags $(\mathbf{t})$ can be seen.
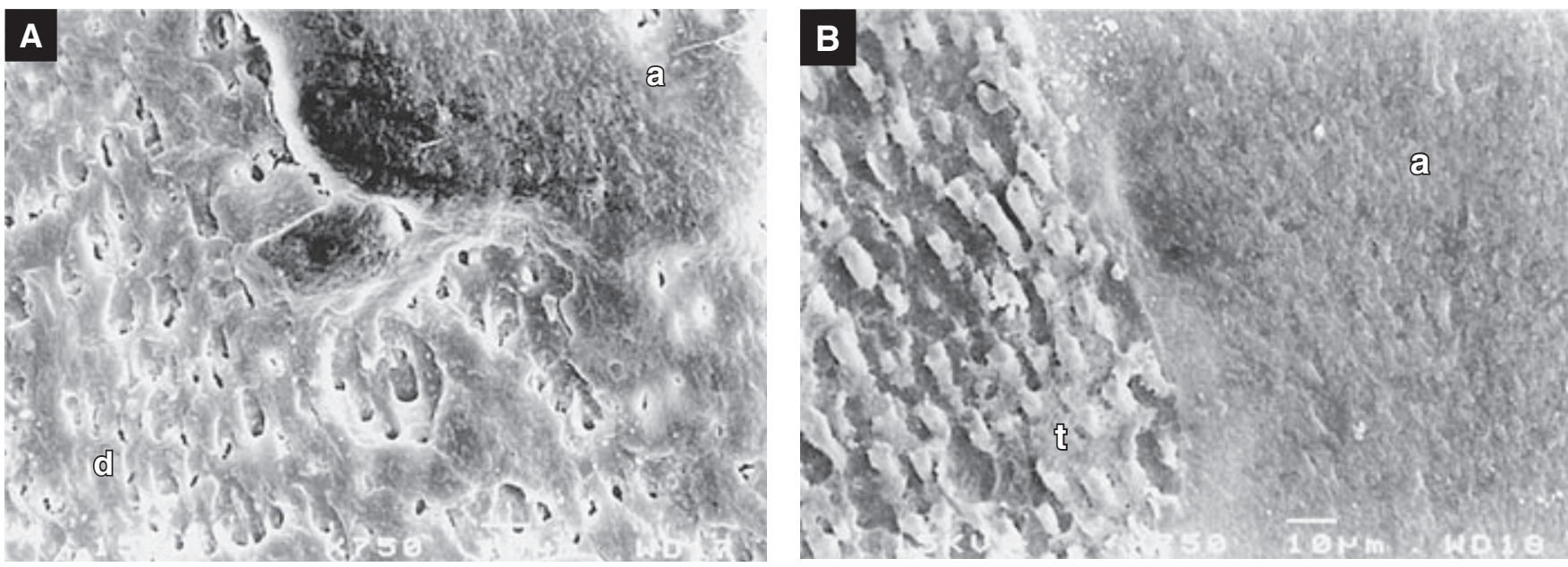

FIGURES 2A AND 2B - Scanning electron micrographs of the dental fragment in 2A (750 X) and composite resin fragment in 2B (SC group) (750 X). The adhesive layer covering part of these surfaces (a), obliterated dentinal tubule apertures (d), and fractured resin tags (t) can be seen.

another part, it can be noted that the adhesive layer and the composite resin are covering the dentin (cohesive fracture). Figure 1B (PTC group) shows the adhesive layer, the composite resin and the fractured resin tags attached to the adhesive layer, confirming the data observed in Figure 1A (its pair).

Figure 2A (SC group) shows another kind of mixed fracture where part of the fracture occurred inside the adhesive layer, probably just under the hybrid layer, because part of the dentinal tubule aperture is open (adhesive fracture), and part is covered by the adhesive layer (cohesive fracture). Figure 2B (SC group) shows the fractured adhe- sive layer (cohesive fracture) and the presence of fractured resin tags still attached to it (adhesive fracture).

Another kind of adhesive fracture can be observed in Figures 3A and 3B (SC group). In the resin fragment (Figure 3B), it can be seen that the fracture occurred just under the hybrid layer or inside it, where fractured resin tags could be seen, attached to the composite resin surface. In its corresponding dentin fragment (Figure 3A), the apertures of the dentinal tubules completely free of resin tags due to the action of the acidic primer of CSEB can be seen. 

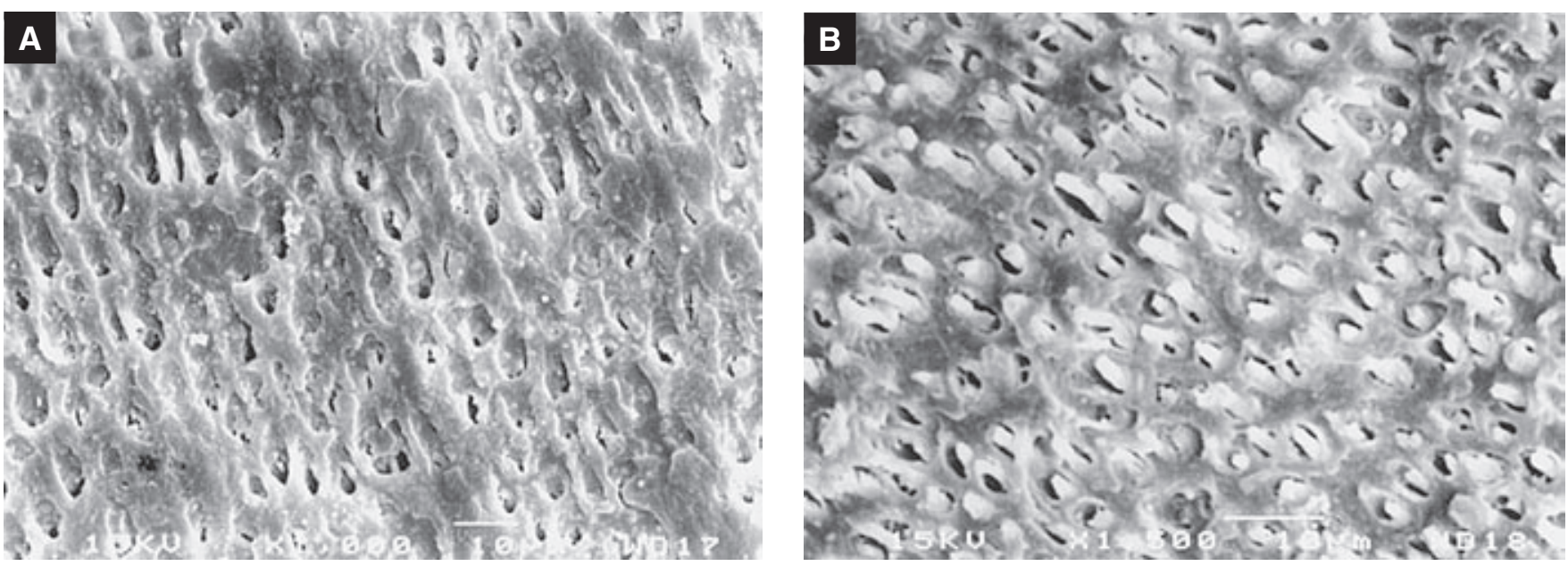

FIGURES 3A AND 3B - Scanning electron micrographs of the fractured surfaces (SC group). In 3A, the dentin surface and dentinal tubule apertures can be noted $(1,000 \mathrm{X})$. In $\mathbf{3 B}$, the fractured dentin that remained attached to the adhesive layer and the dentinal tubules obliterated by resin tags can be noted (1,500 X).

TABLE 3 - ANOVA test.

\begin{tabular}{l|r|r|r|r|r|r}
\hline \hline \multicolumn{1}{c|}{ Variables } & \multicolumn{1}{c|}{ DF } & \multicolumn{1}{c|}{ SEQ SS } & \multicolumn{1}{c|}{ ADJ SS } & \multicolumn{1}{c|}{ ADJ MS } & \multicolumn{1}{c}{ F } & \multicolumn{1}{c}{ P } \\
\hline Substance & 2 & 202.06 & 202.06 & 101.03 & 2.38 & 0.102 \\
\hline Adhesive & 1 & 932.13 & 932.13 & 932.13 & 21.95 & 0.000 \\
\hline Substance versus adhesive & 2 & 63.35 & 63.35 & 31.68 & 0.75 & 0.479 \\
\hline Error & 54 & $2,292.66$ & $2,292.66$ & 42.46 & & \\
\hline Total & 59 & $3,490.20$ & & & & \\
\hline \hline
\end{tabular}

The statistical analyses of the data obtained from the bond strength tests, through the ANOVA test (Table 3), homogeneity analysis and residue analysis demonstrated that there were no statistical differences among the cleaning techniques used ( $p=0.102)$, or among their interactions with the dental adhesive systems $(p=0.479)$. Statistical differences were found between the adhesive systems used ( $p<0.001)$. The comparison of SBMP and CSEB control groups showed that the bond strength of the self-etching system was higher than that of the all-etch system.

\section{DISCUSSION}

The various cleaning agents used on the cavity walls aim to improve the interaction between dentin and restoration material, thus minimizing microleakage.

The use of different treatments on the dentin surface causes different effects on the smear layer, from its total removal by the action of $37 \%$ phosphoric acid ${ }^{4}$ to its partial removal when non-demineralizing or slightly demineralizing treatments are used ${ }^{10}$. These effects help the physicochemical interaction between some adhesive systems and the dentin, providing a satisfactory restorative material/tooth interaction. The kind of treatment used on the cavity walls $\mathbf{s}^{5,6,8,9}$ may vary according to the restoration material used ${ }^{15}$.

It is known that CSEB has demonstrated bond strength similar to or superior than $\mathrm{SBMP}^{2,16}$, as occurred in this study, mainly comparing the control groups. When SBMP is used, the total removal of the smear layer by the acid conditioning produces a demineralized dentinal substratum, favoring the interaction with this adhesive system, helping its penetration inside dentinal tubules and into the intertubular collagen network to originate resin tags and the hybrid layer, thus benefiting bond strength. If some kinds of contaminants are present on the dental surface, these could interfere with the phosphoric acid action. On the other hand, when CSEB is used, the smear layer accumulated on the surface is incorporated into the hybrid layer ${ }^{12}$. Probably, its presence does not influence the interaction between CSEB and dentin, unless the smear layer presents so many 
Rosin C, Arana-Chavez VE, Garone Netto N, Luz MAAC. Effects of cleaning agents on bond strength to dentin. Braz Oral Res 2005;19(2):127-33.

contaminants that it can interfere with the action of the acidic monomer and acids.

The efficacy of the pumice paste method was compared statistically to the sodium bicarbonate jet as cleaning agents, and both seemed to be equivalent, just evidencing different behaviors when related to the different adhesive systems used in this investigation. It probably occurred because dentin acid conditioning is not used with CSEB. Therefore, even when remains of sodium bicarbonate are present, they probably do not interfere with the action of the acidic monomers and the organic acids present in its primer. These remaining particles may be incorporated into the hybrid layer as well as into the smear layer. On the other hand, residues of sodium bicarbonate and changes in superficial $\mathrm{pH}$ probably interfere with the action of the phosphoric acid, affecting SBMP and dentin interaction, as Armas-Vega ${ }^{1}$ (2001) observed when studying resin/enamel interaction.

The significant difference found between SBMP and CSEB groups $(p<0.001)$, regarding bond strength, is probably based on their inherent characteristics and their different techniques of application. SBMP has been formulated to work over the dentin free of smear layer, with open tubule apertures and therefore more humid, and the use of phosphoric acid can cause excessive demineralization (over etching). A more vigorous air jet applied on demineralized dentin can cause the collapse of the collagen network originating areas where the adhesive does not penetrate, thus jeopardizing adhesion ${ }^{11}$. In contrast, excessive humidity (overwet) in the cavity walls, caused by dentinal permeability or due to vestiges of operative procedures, mostly on the axial wall, is a factor that needs attention when CSEB, suitable to act in the presence of the smear layer, is used. Its hydrophobic monomer does not spread well through dentin, forming globules inside this aqueous environment, affecting adhesive infiltration and, consequently, adhesion to this dentinal surface ${ }^{11}$.

Thus, the cleaning techniques studied here may be used with the aim of making the smear layer become a tenuous layer with or without minimum hexogen contaminants that could interfere with the adhesive systems and dentin interactions. Therefore, the clinical use of SBMP and CSEB should be considered carefully, and the use of these substances should follow the manufacturer's instructions strictly, in order to obtain the best clinical results.
SEM observations of traction fractures showed that the predominant pattern of fracture was very well distinct and characterized adhesive and cohesive failures. This differs from that observed by Sol et al. ${ }^{14}$ (2000), who reported only the occurrence of cohesive failures, and Perdigão et al. ${ }^{12}$ (1994), who observed only the occurrence of adhesive failures, when using the same adhesive systems. In this study, cohesive failures both in the composite resin and in the interface adhesive/resin were observed, in agreement with results of previous investigations ${ }^{11,16}$. These results considering kinds of fractures were more or less regular in all groups, confirming the results of the traction tests, since there were no statistical differences in the cleaning technique effects, just in the adhesive effects.

Therefore, based on statistical analysis, it can be stated that the different treatments applied to the dentinal surface in the present study showed equivalent effects to those observed by SEM for both adhesive systems used. This study reflects an established universe and the increase of the sample in a future study may probably provide results that are more revealing and closer to the reality of clinical practice.

\section{CONCLUSIONS}

Based on the results from this investigation, it can be concluded that:

- Previous surface cleaning using sodium bicarbonate jet or pumice/water plus a biological detergent did not interfere with bond strength of both adhesive systems to dentin.

- Clearfil SE Bond adhesive system showed higher bond strength to dentin than Scotchbond Multi-Purpose Plus adhesive system, under these experimental conditions.

- SEM observations regarding the kind of fracture showed a predominance of mixed fractures presenting adhesive and cohesive failures.

\section{ACKNOWLEDGMENTS}

We thank professor Márcia Martins Marques for helping prepare the specimens for SEM analysis. 
Rosin C, Arana-Chavez VE, Garone Netto N, Luz MAAC. Effects of cleaning agents on bond strength to dentin. Braz Oral Res 2005; 19(2):127-33.

\section{REFERENCES}

1. Armas-Vega ADC. Avaliação da influência de diferentes técnicas de limpeza da superficie do esmalte na resistência adesiva, em dentes bovinos [Tese de Mestrado]. São Paulo: Faculdade de Odontologia da USP; 2001.

2. Besnaul C, Attal J. Influence of a simulated oral environment on dentin bond strength of two adhesive systems. Am J Dent 2001;14(6):367-72.

3. Bester SP, de Wet FA, Nel JC, Driessen CH. The effect of airbone particle abrasion on the dentin smear layer and dentin: an in vitro investigation. Int $\mathrm{J}$ Prosthodont 1995;8(1):46-50.

4. Chiba M, Itoh K, Wakumoto S. Effect of dentin cleansers on the bonding efficacy of dentin adhesive. Dent Mater $\mathrm{J}$ 1989;8(1):76-85.

5. Coli P, Alaeddin S, Wennerberg A, Karlsson S. In vitro dentin pretreatment: Surface roughness and adhesive shear bond strength. Eur J Oral Sci 1999;107(5):400-13.

6. Crim GA, Shay JS. Effect of dentin pretreatment procedures on the microleakage of a dentin bonded composite resin material. Quintessence Int 1988;19(5):365-7.

7. Galloway SE, Pashley DH. Rate of removal of root structure by the use of the Prophy-Jet device. J Periodontol 1987;58(7):464-9.

8. Hoeppner MG, Sundfeld RH, Holland Júnior C, Sundfeld MLMM. Análise microscópica da penetração in vitro de um selante de fóssulas e fissuras no esmalte dental humano: efeitos da profilaxia e dos tempos de condicionamento ácido do esmalte dental. Rev Bras Odontol 1998;55(5):258-64.
9. Kanca JA, Gwinnett AJ. Successful marginal adaptation of a dentin-enamel bonding system in vitro and in vivo. $\mathrm{J}$ Esthet Dent 1994;6(6):286-94.

10. Luz MAAC, Garone Netto N, Arana-Chavez VE, Sobral MAP, Singer JM. Evaluation of chemical and/or mechanical treatments of the smear layer as revealed by scanning electron microscopy - a blind comparative study. Pesq Odont Bras 2000;14(2):101-6.

11. Nikaido T, Kunzelmann K, Ogata M, Harada N, Yamaguchi $\mathrm{S}, \mathrm{Cox} \mathrm{CF}$, et al. The in vitro dentin bond strengths of two adhesive systems in Class I cavities of human molars. J Adhes Dent 2002;4(1):31-9.

12. Perdigão J, Swift Jr EJ, Denehy GE, Wefel JS, Donly KJ. In vitro bond strengths and SEM evaluation of dentin bonding systems to different dentin substrates. J Dent Res 1994;73(1):44-55.

13. Salami D, Luz MAAC. Effect of prophylactic treatments on the superficial roughness of dental tissues and of two esthetic restorative materials. Pesqui Odontol Bras 2003; 17(1):63-8.

14. Sol E, Espasa E, Boj JR, Canalda C. Effect of different prophylaxis methods on sealant adhesion. J Clin Pediatr Dent 2000;224(3):211-4.

15. Spohr AM, Conceição EN, Pacheco JFM. Tensile Bond strength of four adhesive systems to dentin. Am J Dent 2001;14(4):247-51.

16. Toledano M, Osorio R, De Leonardi G, Rosales-Leal JI, Ceballos L, Cabrerizo-Vilchez MA. Influence of self-etching primer on the resin adhesion to enamel and dentin. Am J Dent 2001;14(4):205-10.
Received for publication on Nov 30, 2004

Sent for alterations on May 09, 2005

Accepted for publication on Jun 22, 2005 